\section{COLLAGEN EXTRACTION FROM YELLOWFIN TUNA (Thunnus albacares) SKIN AND ITS ANTIOXIDANT ACTIVITY}

Mala Nurilmalaa*, Shita Fauzib, Dian Mayasarib, Irmanida Batubara,b,c

aDepartment of Aquatic Product Technology, Faculty of Fisheries and Marine Science, Bogor Agricultural University, Bogor, Indonesia

bChemistry Department, Faculty of Mathematics and Sciences, Bogor Agriculture University, Bogor, Indonesia

cTropical Biopharmaca Research Center, Bogor Agricultural University
Article history

Received

11 September 2017

Received in revised form

24 August 2018

Accepted

1 December 2018

Published online

18 February 2019

*Corresponding author mnurilmala@ipb.ac.id
Graphical abstract

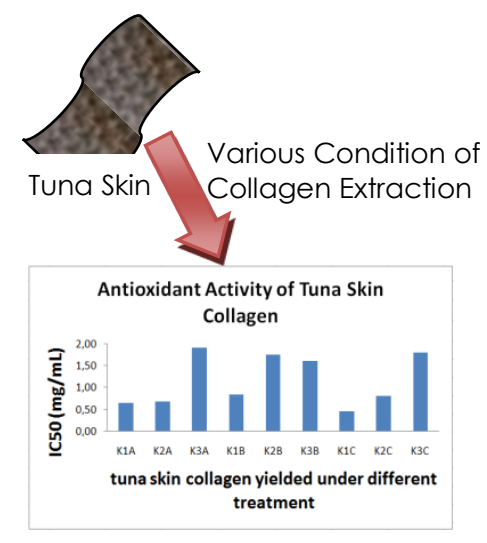

\begin{abstract}
Tuna skin, a byproduct of the fish processing industry, is used as an alternative collagen source to replace bovine and porcine products. This study aimed to extract collagen from tuna skin with acetic acid, and investigated the antioxidant activity. Collagen extraction was carried out through a pretreatment process, defatted with butyl alcohol, and soaking in acetic acid to extract the Acid Soluble Collagen (ASC). The effect of concentration of sodium hydroxide and soaking time on the non-collagenous protein removed were measured, and evaluated. The yield and antioxidant activity of each sample were evaluated and the best result was determined by ANOVA. The highest yield of collagen was $3.18 \%$ based on dry weight reached at the treatment with sodium hydroxide $0.2 \mathrm{M}$ and acetic acid $1 \mathrm{M}$. The different treatments did not result in any significant differences in the spectrum of amide A, B, I, II and III which are the characteristics spectra of collagen. Based on the electrophoretic pattern, tuna skin collagen has two a chains ( $a 1$ and $a 2$ ), and one $\beta$ chain. Therefore, it is classified as type I collagen. The main amino acids were glycine and proline. In addition, the strongest antioxidant activity was found in the sample treated with sodium hydroxide $0.05 \mathrm{M}$ and acetic acid $1 \mathrm{M}$ treatment with $\mathrm{IC}_{50}$ value of $0.45 \mathrm{mg} / \mathrm{mL}$. This study is the first to report on antioxidant activity from fish collagen (not hydrolysate or peptide products).
\end{abstract}

Keywords: Collagen, tuna, antioxidant, extraction

\subsection{INTRODUCTION}

Collagen, a biomaterial protein, is widely used in different industrial products such as cosmetics and pharmaceutics. It has been known that conventional collagen comes from bovine and porcine. The use of collagen from these sources may cause problems due to certain health issues, and religious sentiments. Thus, it is necessary to explore another source of collagen in order to meet the "halal" requirements, especially in Islamic countries.

Tuna is the second most exported fish in Indonesia. The quality of tuna meat can be determined by its colour as well as myoglobin profile, and the soluble water protein [1]. The characterization of tuna myoglobin is closely related with its primary structure, and its autoxidation profile which helps keep the freshness of tuna [2]. However, 
some parts of tuna have not been widely used; one of them is the skin.

In this research, tuna skin was used as an alternative source of collagen. Some researchers have reported on the use of fish byproduct as collagen [3, 4, 5, 6, 7]. Fish collagen has smaller molecular structure than collagen derived from land animals so it is easier to be absorbed by the human body [8]. Moreover, the characteristics of collagen obtained depend on the condition of the raw materials, and its processes $[9,10,11,12]$. Therefore it is necessary to perform optimization of the extraction conditions.

There have been few reports regarding the optimization of the extraction process, and conditions against the physico-chemical properties of fish skin collagen especially from tuna. In addition, there is no report on antioxidant activity of its contained collagen. Previous investigations have reported bioactive properties such as antioxidant activity from fish collagen-derived products, namely collagen hydrolysates, or collagen peptides [8, 11].Therefore, this study aimed to carry out the best practice for the extraction condition of acid soluble collagen (ASC) from tuna skin (Thunnus albacares), and to evaluate its general antioxidant activity.

\subsection{METHODOLOGY}

Tuna (Thunnus albacares) fish skin was obtained from an Indonesian tuna processing company in Celebes Island, Indonesia. This raw material was stored in a freezer with temperatures up to $-20^{\circ} \mathrm{C}$ before being used. The other chemicals used for this study were purchased from Sigma Aldrich Co. at an analytical grade.

\subsection{Proximate Analysis}

Preparation was done by separating the skin from other parts of the fish. The fish skin was then cut into small sizes and kept frozen in the freezer (temperature $-20^{\circ} \mathrm{C}$ ) before being used for the further process. Moisture, ash and protein contents were analyzed by following official method of analysis of AOAC [13].

\subsubsection{Determination of Water Content}

To determine the moisture content of tuna skin, about $3 \mathrm{~g}$ sample was weighed in the dried dish and placed in the oven at $105^{\circ} \mathrm{C}$ for 3 hours. After drying, it was transferred to a desiccator and then reweighed. Moisture content was calculated by comparing the weight of dried sample to the wet sample, and was presented as percent.

\subsubsection{Determination of Ash Content}

About $5 \mathrm{~g}$ sample was placed in the crucible, and heated at $550^{\circ} \mathrm{C}$ in the furnace overnight. When the sample turned to gray, it was then placed in a desiccator and reweighed. Ash content was calculated by comparing the weight of ash content to the wet sample, and was presented as percent.

\subsubsection{Determination of Protein Content}

About $1 \mathrm{~g}$ sample was digested with sulfuric acid. The nitrogen released was determined by titration technique, and then calculated with conversion factor of 6.25.

\subsection{Pretreatment Sample}

To remove non-collagenous proteins, the prepared fish skin was pretreated by following the method used by Singh et al. [14] with slight modifications. Fish skin was mixed with three different concentrations of sodium hydroxide $10.05,0.10$, and $0.20 \mathrm{M}$, respectively), then soaked for 8 hours where the alkali solution was changed every 2 hours. The concentration of protein for each alkali solution was determined using biuret method [15] to evaluate both the effect of sodium hydroxide concentration and soaking time to the protein removal effectiveness in this pretreatment step. Next, the treated skin was washed with water of temperature $4-8^{\circ} \mathrm{C}$ until a neutral $\mathrm{pH}$ of wash water was reached. The skin was then defatted with $10 \%$ butyl alcohol with a solid to solvent ratio of 1:4 (w/v) for 24 hours. This step aimed to remove fat in the skin only, and there is no parameter measured in this step.

\subsection{Optimization of Collagen Extraction}

Acid solubilized collagen (ASC) was extracted through the method used by Singh et al. [14] with slight modifications. The pretreated skin was submerged in three different concentrations of acetic acid $(0.05,0.50$, and $1 \mathrm{M}$ ) with a solid to solvent ratio of 1:15 (w/v) for 24 hours. After the first and second hour of this soaking step, the weight of the fish skin was determined to evaluate the degree of swelling. The degree of swelling was obtained by comparing the difference in the weight of tuna skin before and after soaking in acetic acid, and then presented in percent.

The mixture was filtered through fabric 300 mesh size, and the filtrates were then collected. The collagen was precipitated by adding sodium chloride. The precipitate of the initial skin used was collected [16]. Then the obtained collagen was characterized by fourier transform infrared (FTIR) to determine the functional groups [10], ultra performance liquid chromatography by centrifugation (Himac CR 21G, Hitachi Koki Co., Ltd. Japan) $17.700 \times \mathrm{g}$ for 1 hour. The pellet was dialyzed against acetic acid, followed by the dialysis of distilled water. The dialysate was freeze dried, and was referred to as "K1A, K1B, K1C, K2A, K2B, K2C, $\mathrm{K} 3 \mathrm{~A}, \mathrm{~K} 3 \mathrm{~B}$, and K3C". The yield of ASC was calculated from the percentage of dry weight of collagen 
extracted in comparison with the wet weight (UPLC) to determine its amino acids, and sodium dodecyl sulphate-polyacrylamide gel electrophoresis (SDSPAGE) [17] to determine molecular weight of peptide chain contained in tuna skin collagen.

\subsection{Determination of The Yield of Collagen}

The yield of collagen was determined by comparing the dried weight of collagen yielded to the weight of wet tuna skin used. The result was presented in percent.

\subsection{Functional Group Analysis with Fourier Transform Infra Red (FTIR)}

About $2 \mathrm{mg}$ collagen was well mixed with $200 \mathrm{mg} \mathrm{KBr}$ until homogen, then put into a pellet mould, and compacted. The pellet was inserted into the cell, and fired with IR beam from the IR-408 infrared spectroscopy that had been turned on under stable conditions. Absorption was then recorded, and displayed as qualitative data.

\subsection{Determination of Molecular Weight of Collagen by SDS-PAGE}

Collagen was added with SDS $5 \%$ solution $(b / v)$ in the ratio of $2 \mathrm{mg} \mathrm{SDS}$ for every $1 \mathrm{~mL}$ sample. The solution was incubated in the water bath $85^{\circ} \mathrm{C}$ for 1 hour, and centrifuged $8000 \mathrm{rpm}$. Buffer was added to the filtrate in the ratio $1: 1$, and reheated in water bath $85^{\circ} \mathrm{C}$ for 10 minutes. The treated sample was then injected to the well with $12.5 \%$ of separating gel and $3 \%$ of stacking gel. Molecular weight of peptida was determined by comparing the bands of the sample to the marker.

\subsection{Determination of Amino Acids Content}

About $0.1 \mathrm{~g}$ of dried collagen was added with a $5 \mathrm{~mL}$ $\mathrm{HCl} 6 \mathrm{~N}$ solution. The solution was hydrolyzed at $110^{\circ} \mathrm{C}$ for 22 hours. Subsequently, the solution was cooled and transferred into a $50 \mathrm{~mL}$ measuring flask and added with distilled water. Samples were filtered using a $0.45 \mu \mathrm{m}$ filter. The solution was then prepared and loaded to the UPLC column.

\subsection{Determination of Antioxidant Activity}

Antioxidant activity was determined according to the method used by Batubara et al. [18] with DPPH (2,2-difenil-1-pikrilhidrazil). Ascorbic acid was used as positive control while ethanol was used as negative control. About $100 \mu \mathrm{L}$ sample solution was added by $100 \mu \mathrm{L}$ DPPH, and were incubated in a dark room temperature for 30 minutes. Absorbance was determined with microplate reader at wavelength of $517 \mathrm{~nm}$ then the inhibition activity was determined.

\subsection{Experiment Modeling and Data Analysis}

The experiment modeling, and data analysis was done according to the method described by Steel and Torrie [19]. The design used for pretreatment step with $\mathrm{NaOH}$ is a completely randomized design (CRD). The treatment is a combination of concentration of $\mathrm{NaOH}$ with soaking time. All treatments were performed in three replicates.

The design used for the soaking step with acetic acid is a factorial completely randomized design (FCRD) with two factors (three levels concentration of acetic acid, and two levels of soaking time). All treatments were carried out in three replicates. Data was analyzed by Analysis of Variances (ANOVA). If there was a significant difference, it was followed by Duncan's Multiple Range Test (DMRT) at the level of $95 \%$.

\subsection{RESULTS AND DISCUSSION}

\subsection{Chemical Composition of Tuna Skin}

The chemical composition of raw tuna skin was analyzed to determine the quality of the skin used. The examined tuna skin contained $61.50 \%$ of moisture, $0.72 \%$ of ash, and $6.74 \%$ of protein.

The moisture content indicates the water content of the skin used, while the protein content indicates the maximum possible amount of collagen that could be extracted. As shown by the results of this analysis, the moisture content in tuna fish skin was quite high, while the protein content was quite low. This high moisture content was predictable based on the storage process used for freezing.

\subsection{Pretreatment of Sample}

Pretreatment with sodium hydroxide was performed in order to remove non-collagenous proteins in the fish skin. Previous research has reported that alkali solutions show effect on removing non-collagen substances during pretreatment process [20].

The alkali solution used in this process was sodium hydroxide in three different concentrations $(0.05 \mathrm{M}$, $0.1 \mathrm{M}$, and $0.2 \mathrm{M}$ ) with 8 hours soaking time, and the solvent was changed every 2 hours. The dissolved protein was determined by biuret method.

The effect of increasing soaking times to the noncollagenous protein was evaluated. The value of removed protein was used as the dependent variable while soaking time was used as the factor. To investigate the effect of soaking time, different variables of concentration of sodium hydroxide were eliminated. Table 1 shows the value of noncollagenous protein removed by sodium hydroxide with various soaking times. The highest value of removed protein by sodium hydroxide was during 2 hours soaking, and that value decreased with additional soaking time. Analysis of Variances (ANOVA) showed that the first 2 hours of soaking time 
had a significant different effect ( $p>0.05)$. This indicated that non-collagenous protein in the skin has been removed optimally in the first 2 hours of soaking time; while its value did not significantly increase with additional soaking time. This treatment was further chosen for the next step.

Table 1 Non-collagenous protein removed with various soaking times

\begin{tabular}{cc}
\hline Soaking time $(\mathrm{h})$ & $\begin{array}{c}\text { Protein dissolved in } \mathrm{NaOH} \\
(\mathbf{m g} / \mathbf{m L})\end{array}$ \\
\hline 2 & $1.03 \pm 0.21^{\mathrm{a}}$ \\
4 & $0.45 \pm 0.10^{\mathrm{b}}$ \\
6 & $0.33 \pm 0.12^{\mathrm{bc}}$ \\
8 & $0.21 \pm 0.08^{\mathrm{c}}$
\end{tabular}

Note: value with different superscript letters are significantly different at $\mathrm{p}<0.05$ level

The effect of different concentrations of sodium hydroxide used for pretreatment has also been evaluated, and the result is shown in Table 2. In this step, the value of removed protein was used as the dependent variable while the three different concentrations of sodium hydroxide were used as the factor. To study the effect of sodium hydroxide concentrations to the protein removal effectiveness, the different soaking time variable was eliminated. Analysis of variance (ANOVA) showed that concentration of sodium hydroxide did not have significantly different effect ( $p>0.05$ ) to removal of protein during the pretreatment process.

Table 2 Non-collagenous protein removed with various concentrations of sodium hydroxide

\section{$[\mathrm{NaOH}](\mathrm{M}) \quad$ Protein dissolved in $\mathrm{NaOH}(\mathrm{mg} / \mathrm{mL})$}

\begin{tabular}{cc}
0.05 & $0.43 \pm 0.34{ }^{a}$ \\
0.10 & $0.54 \pm 0.36 a$ \\
0.20 & $0.53 \pm 0.35^{a}$ \\
\hline $\begin{array}{l}\text { Note: value with different superscript letters are significantly } \\
\text { different at } p<0.05 \text { level }\end{array}$
\end{tabular}

From Table 2, it can be seen that removed protein by sodium hydroxide $0.1 \mathrm{M}$ was slightly higher than sodium hydroxide $0.05 \mathrm{M}$. However, the value was almost the same with the removed protein by the higher concentration. This is in line with the result reported by Zhou and Regenstein [20] that the concentration of alkali solution higher than $0.1 \mathrm{M}$ did not have a significant effect on the value of removed protein.

\subsection{Collagen Extraction with Acetic Acid}

This step was performed in order to extract collagen in tuna skin. Ahmad and Benjakul [3] reported that acetic acid had caused the breakdown of intramolecular hydrogen bonding that stabilizes the collagen triple helix structure. This process causes skin swelling because water molecules are trapped in the collagen fibres. This swelling is important because it facilitates the extraction of collagen through the disruption of non-covalent bonds. The parameter measured in this step was the degree of tissue swelling, measured at the first and second hour of soaking time. This was done to evaluate the increase in swelling level from hour to hour. In the case of effect of acetic acid concentration to the degree of swelling, the degree of swelling in the first hour of soaking time was evaluated (see Table 3). Samples soaked in higher concentrations of acetic acid showed a higher degree of swelling.

Table 3 Effect of acetic acid concentration to the degree of swelling in the first hour of soaking time

\section{$\left[\mathrm{CH}_{3} \mathrm{COOH}\right](\mathrm{M})$ for extraction Degree of Swelling (\%)}

\begin{tabular}{cc}
\hline $0.05 \mathrm{M}$ & $161.49 \pm 40.28 \mathrm{a}$ \\
$0.5 \mathrm{M}$ & $233.96 \pm 47.93^{\mathrm{b}}$ \\
$1 \mathrm{M}$ & $241.96 \pm 39.41^{\mathrm{b}}$
\end{tabular}

Note: value with different superscript letters are significantly different at $p<0.05$ level

The effect of the concentration of acetic acid used for extraction and soaking time to the degree of swelling is shown in Table 4. The higher concentration of acetic acid in combination with longer soaking time produced a higher degree of swelling. It can be seen that sample K2B with 2 hours soaking time had the highest degree of swelling (356.60 \pm 78.52$)$ percentage. Sample K2B did not show significantly different effect ( $p>0.05$ ) with K3C on swelling degree indicating concentration of $0.5 \mathrm{M}$ and $1 \mathrm{M}$ acetic acid had a similar effect. Soaking time was continued for 24 hours following the method used by Singh et al. [14]. High degrees of swelling indicate a high amount of water that can be absorbed by tuna skin. In this way the collagen fibres can become easier to separate, which supports the process of extraction of collagen in the next step. 
Table 4 Different conditions to extract collagen from tuna skin, degree of swelling, yield and IC 50 of antioxidant activity

\begin{tabular}{|c|c|c|c|c|c|c|}
\hline $\begin{array}{l}\text { Sample } \\
\text { name }\end{array}$ & $\begin{array}{l}\underset{\mathrm{NaOH}](\mathrm{M})}{\mathrm{for}} \\
\text { pretreatment }\end{array}$ & $\begin{array}{c}{\left[\mathrm{CH}_{3} \mathrm{COOH}\right]} \\
(\mathrm{M}) \\
\text { for } \\
\text { extraction }\end{array}$ & $\begin{array}{l}\text { Degree of } \\
\text { swelling (\%) in } \\
\text { first hour }\end{array}$ & $\begin{array}{l}\text { Degree of swelling } \\
\text { in second hour (\%) }\end{array}$ & $\begin{array}{l}\text { Collagen } \\
\text { yield (\%) }\end{array}$ & $\begin{array}{c}\mathrm{IC}_{50} \\
(\mathrm{mg} / \mathrm{mL})\end{array}$ \\
\hline $\mathrm{K} 1 \mathrm{~A}$ & 0.05 & 0.05 & $164.14 \pm 68.55^{\mathrm{ab}}$ & $210.36 \pm 76.90 \mathrm{ab}$ & $0.42 \pm 0.23 a b$ & $0.64 \pm 0.17$ \\
\hline $\mathrm{K} 2 \mathrm{~A}$ & 0.10 & 0.05 & $133.38 \pm 22.88^{a}$ & $207.54 \pm 35.55^{a}$ & $0.72 \pm 0.08 \mathrm{abc}$ & $0.68 \pm 0.11$ \\
\hline $\mathrm{K} 3 \mathrm{~A}$ & 0.20 & 0.05 & $186.94 \pm 0.16 \mathrm{ab}$ & $291.43 \pm 31.30 \mathrm{ab}$ & $0.30 \pm 0.32 a$ & $1.90 \pm 1.03$ \\
\hline $\mathrm{K} 1 \mathrm{~B}$ & 0.05 & 0.50 & $242.71 \pm 84.59 \mathrm{ab}$ & $317.30 \pm 111.53 \mathrm{ab}$ & $2.06 \pm 1.27 \mathrm{~cd}$ & $0.84 \pm 0.29$ \\
\hline $\mathrm{K} 2 \mathrm{~B}$ & 0.10 & 0.50 & $242.86 \pm 31.38 \mathrm{ab}$ & $356.60 \pm 78.52^{b}$ & $1.32 \pm 0.46 \mathrm{abc}$ & $1.75 \pm 0.80$ \\
\hline $\mathrm{K} 3 \mathrm{~B}$ & 0.20 & 0.50 & $216.33 \pm 49.09 a b$ & $323.27 \pm 21.35^{\mathrm{ab}}$ & $0.92 \pm 0.17 a b c$ & $1.61 \pm 0.37$ \\
\hline $\mathrm{K} 1 \mathrm{C}$ & 0.05 & 1.00 & $272.23 \pm 25.59 b$ & $335.08 \pm 1.62 \mathrm{ab}$ & $1.62 \pm 0.05 \mathrm{abc}$ & $0.45 \pm 0.27$ \\
\hline $\mathrm{K} 2 \mathrm{C}$ & 0.10 & 1.00 & $230.65 \pm 3.36 \mathrm{ab}$ & $332.20 \pm 11.05^{\mathrm{ab}}$ & $1.91 \pm 1.04 \mathrm{bcd}$ & $0.81 \pm 0.50$ \\
\hline $\mathrm{K} 3 \mathrm{C}$ & 0.20 & 1.00 & $223.02 \pm 65.51 \mathrm{lab}$ & $348.92 \pm 59.80 \mathrm{ab}$ & $3.18 \pm 0.47 d$ & $1.79 \pm 1.67$ \\
\hline
\end{tabular}

Note: value with different superscript letters in each column are significantly different at $p<0.05$ level

\subsection{Yield of Collagen}

Sample $\mathrm{K} 3 \mathrm{C}$ has the highest yield which is equal to $3.18 \pm 0.47 \%$ (see Table 4). Collagen extracted by acetic acid at a concentration of $1 \mathrm{M}$ has a higher value in degree of swelling, and provided the highest yield. Potaros et al. [21] stated that the difference in the value of the yield of collagen extraction can be seen as a result of different extraction methods, and the condition of material used.

The effect of acetic acid concentrations on the yield of collagen was then evaluated. The samples were grouped by different concentrations of acetic acid. The means of the yield of each collagen with different concentrations of sodium hydroxide in the same group of concentration of acetic acid were calculated (see Table 5). The yield of collagen extraction is directly proportional to the concentration of acetic acid used. However, the acetic acid concentration of more than $0.5 \mathrm{M}$ did not show any significant effect.
Table 5 Effect of acetic acid concentration to yield of collagen

\begin{tabular}{cc}
\hline $\begin{array}{c}{\left[\mathrm{CH}_{3} \mathrm{COOH}\right](\mathrm{M}) \text { for }} \\
\text { extraction }\end{array}$ & Yield (\%) \\
\hline $0.05 \mathrm{M}$ & $0,48 \pm 0,26^{\mathrm{a}}$ \\
$0.5 \mathrm{M}$ & $1,43 \pm 0,80^{\mathrm{b}}$ \\
$1 \mathrm{M}$ & $2,23 \pm 0,90^{\mathrm{b}}$ \\
\hline $\begin{array}{c}\text { Notes: value with different superscript } \\
\text { different at } p<0.05 \text { level }\end{array}$ &
\end{tabular}

3.5 Functional Group Analysis with Fourier Transform Infra Red (FTIR)

The results of infrared spectra of collagen showed there are several characteristic peaks of collagen within the infrared spectra (see Figure 1). Amongst these are amide $A$ with a spectrum around $3300 \mathrm{~cm}^{-1}$ (NH stretching), amide $\mathrm{B}$ at around $3100 \mathrm{~cm}^{-1}(\mathrm{NH}$ stretching), amide I at 1600-1690 $\mathrm{cm}^{-1} \quad(\mathrm{C}=0$ stretching), amide II at 1480-1575 $\mathrm{cm}^{-1}$ (CN stretching and $\mathrm{NH}$ bending), and amide III at $1229-1301 \mathrm{~cm}^{-1}$ (CN stretching and NH bending) [22]. Similar spectra were also found in striped catfish skin as reported by singh et al. [14]. The pattern of the spectrum at each treatment of sample evaluated in this study did not show any significant differences. 


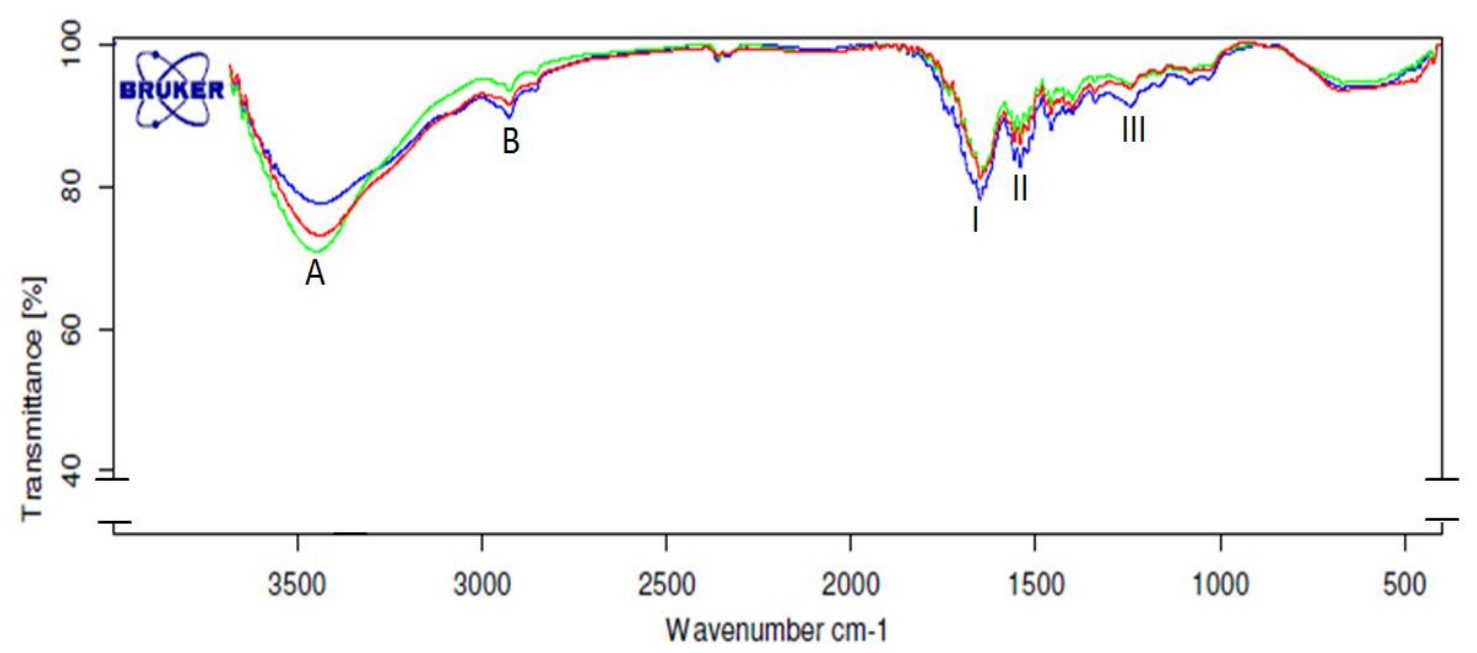

K1A (red). K2A (green). K3A (blue)

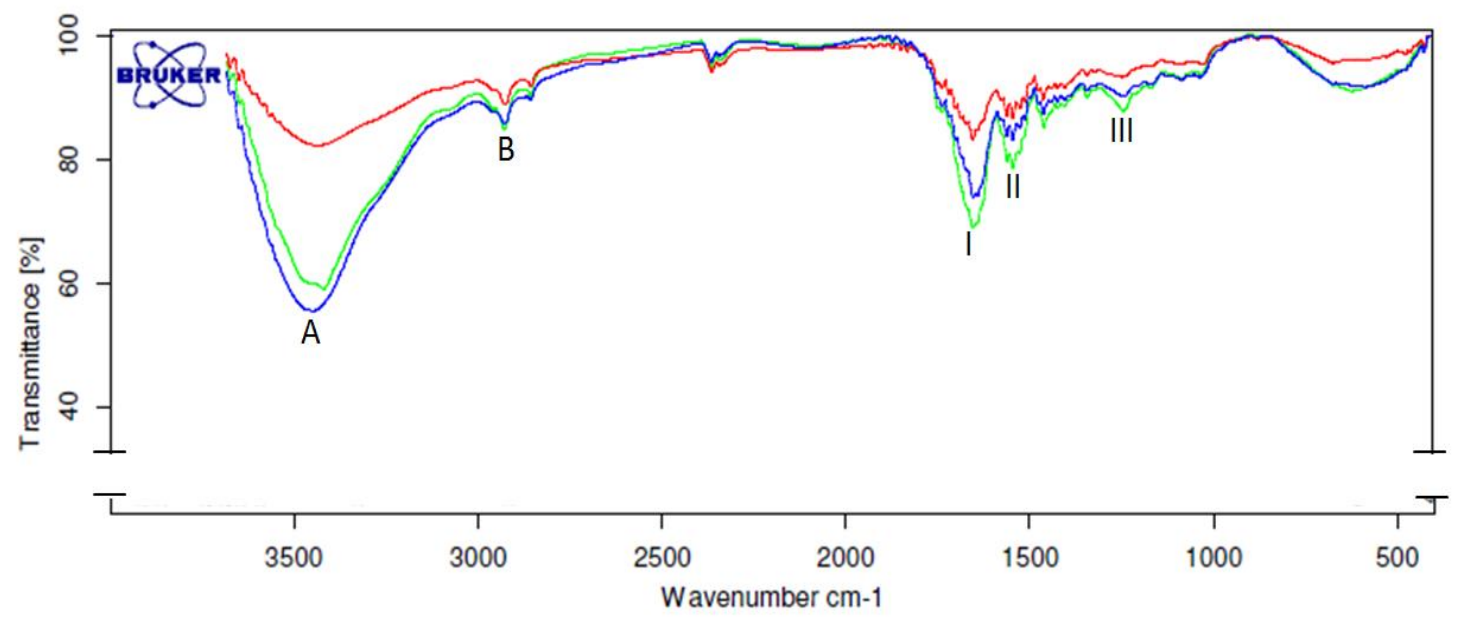

K1B (blue). K2B (red). K3B (green)

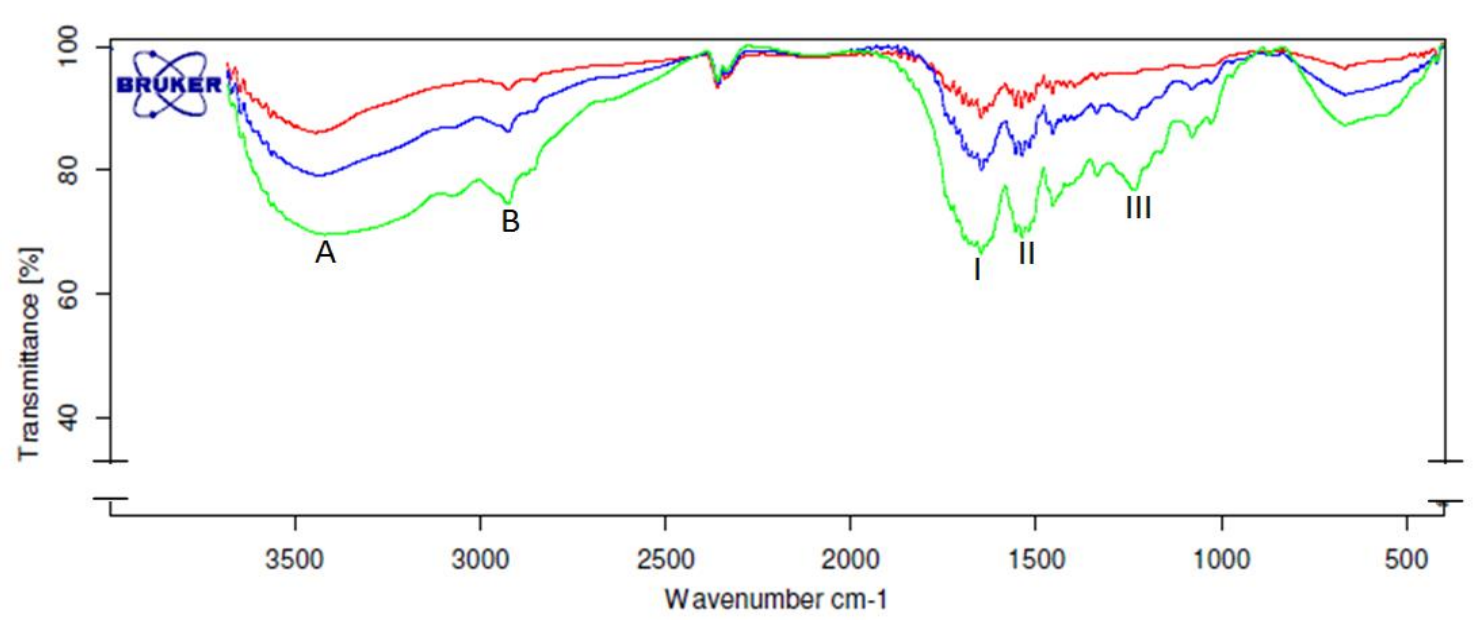

K1C (green). K2C (blue). K3C (red)

Figure 1 FTIR spectrum of tuna skin collagen 


\subsection{Molecular Weight of Collagen by SDS-PAGE}

Collagen contains two a chains ( $\alpha 1$ and a2 chains), and one $\beta$ chain (see Figure 2). Based on these specific bands, this collagens were classified as type I collagen [23]. Similar electrophoretic patterns of type I collagen was also found in the skin of brown stripe red snapper [24], and in the collagen of striped catfish as reported by Sing et al. [14]. Collagen can contain components with high molecular weight including $\alpha, \beta$ chains, indicating cross-linkages in collagen molecules. However, generally the crosslinking of collagen in fish skins was low, and the high cross-linked molecules (Y chain) are rarely found [25].

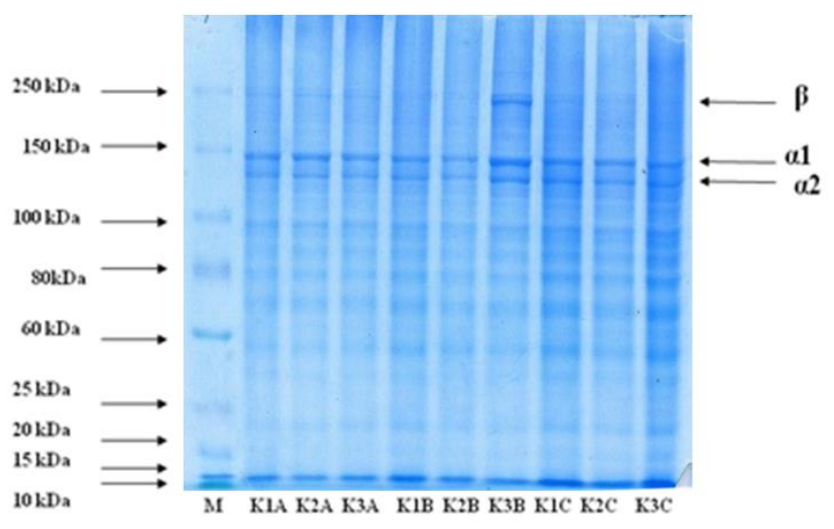

Figure 2 Electrophoregram of marker (M) and each specimen of collagen (K1A-K3C)

3.7 Analysis of Amino Acid with Ultra Performance Liquid Chromatography (UPLC)

Characterization of amino acids to determine the type of amino acid found in collagen was done using Ultra Performance Liquid Chromatography (UPLC). Standard amino acids in this study consisted of 15 types of amino acids. The amino acid analysis was performed on the sample of $\mathrm{K} 3 \mathrm{C}$ (the highest yield of collagen). The result is shown in Table 6. The dominant amino acid in this study was glycine, followed by proline. Glycine is the most dominant amino acid in collagen as has been previously reported $[3,4,5]$.

Table 6 Amino acid contained in tuna skin collagen

\begin{tabular}{ccc}
\hline Num. & Amino acids & Contain (\%) \\
\hline 1 & Histidine & 0.49 \\
2 & Threonine & 2.01 \\
3 & Proline & $\mathbf{5 . 6 0}$ \\
4 & Tyrosine & 0.36 \\
5 & Leucine & 1.44 \\
6 & Aspartic Acid & 2.10 \\
7 & Lysine HCl & 1.70 \\
8 & Glycine & $\mathbf{1 3 . 5 3}$ \\
9 & Arginine & 5.22 \\
10 & Alanine & 4.07 \\
11 & Valine & 1.05 \\
12 & Isoleucine & 0.60 \\
13 & Phenylalanine & 1.58 \\
14 & Glutamic acid & 4.52 \\
15 & Serine & 1.99 \\
\hline
\end{tabular}


Glycine was the most prevalent amino acid in the collagen yielded from tuna skin, which is in line with the fact that the amino acid composition of collagen consists of repeating Gly-Y-X residues in triple helical configuration. The amounts of proline are important for the structural integrity of collagen $[9,11]$.

\subsection{Antioxidant Activity}

Antioxidant activity of collagen in tuna skin is shown as $I C_{50}$ in Table 4. The lower value of $I C_{50}$ shows higher antioxidant activity. Overall, there is no significant effect of each sample to the antioxidant activity. Next, the effect of pretreatment with sodium hydroxide on antioxidant activity was evaluated by calculating the means of the antioxidant activity of each collagen in the same concentrations of sodium hydroxide. Therefore, the antioxidant activity of samples were grouped by sodium hydroxide concentrations, and the result is shown in Table 7

Interestingly, there is significant effect between each group of different sodium hydroxide concentrations used for pretreatment (see Table 7). The alkali solutions break the most of thelopeptide chain of the collagen molecule during the pretreatment process [20], so the different concentrations of alkali solution may cause few different structures of collagen, and affects its antioxidant activity.

Table 7 Effect of different concentrations of sodium hydroxide to the antioxidant activity

\begin{tabular}{cc}
\hline $\begin{array}{c}\text { [NaOH] }(\mathrm{M}) \text { for } \\
\text { pretreatment }\end{array}$ & $\mathrm{IC}_{50}(\mathrm{mg} / \mathrm{mL})$ \\
\hline 0.05 & $0.64 \pm 0.26 \mathrm{a}$ \\
0.1 & $1.08 \pm 0.67 \mathrm{ab}$ \\
0.2 & $1.77 \pm 0.90^{\mathrm{b}}$ \\
\hline $\begin{array}{l}\text { Note: values with different superscript letters are significantly } \\
\text { different at } p<0.05 \text { level }\end{array}$
\end{tabular}

The highest antioxidant activity was found in $\mathrm{K} 1 \mathrm{C}$, with $\mathrm{IC}_{50}$ value of $0.45 \mathrm{mg} / \mathrm{mL}$. This activity is still lower than the ascorbic acid as a positive control $(0.00383$ $\mathrm{mg} / \mathrm{mL}$ ). However, it has been reported that antioxidant activity of collagen hydrolysate was higher [26], presumably because the collagen produced is still in rough shape, while the antioxidant activity of collagen is affected by several factors; one of them is the molecular weight of collagen. This result cannot be compared to similar sources of collagen because there is no report so far for antioxidant activity of collagen from other types of fish skin. However, the antioxidant activity of collagen from the fish skin sample is higher than the antioxidant activity of collagen from pig skin 10.60 $\mathrm{mg} / \mathrm{mL})$. But it is almost similar to the antioxidant activity of collagen from fish scales $(0.42 \mathrm{mg} / \mathrm{mL})$ [27]. It can be assumed that collagen from yellowfin tuna skin is a very good alternative to replace the use of collagen from pig skin as an antioxidant to meet the "halal" requirement, especially in Islamic countries. It has shown to be even more appropriate than collagen from fish scale due to the abundance of tuna skin in comparison to obtainable fish scales. Additionally the collagen could be more easily extracted than collagen from fish scales.

This study is unique as it investigated the antioxidant activity of collagen from fish skin. Therefore, this study provides important information on future use of collagen from fish skin, especially the contained antioxidants.

\subsection{CONCLUSION}

Collagen extraction was performed through a pretreatment process, defatted with butyl alcohol, and soaking in acetic acid to extract the ASC (Acid Soluble Collagen). Collagen extracted from tuna skin has shown to be of type I collagen with glycine and proline as the most dominant amino acids. The highest yield of collagen was reached at treatment with sodium hydroxide $0.2 \mathrm{M}$ and acetic acid $1 \mathrm{M}$. The strongest antioxidant activity was determined within the sample treated with sodium hydroxide 0.05 $M$ and acetic acid $1 M$.

\section{Acknowledgement}

This work was financially supported by the Indonesian Ministry of Research, Technology, and Higher Education through competitive funding in joint research and publication (KLN).

\section{References}

[1] Nurilmala, M., Ushio, H., Kaneko, G., and Ochiai, Y. 2013. Assessment of Commercial Quality Evaluation of Yellowfin Tuna (Thunnus albacares) Meat Based on Myoglobin Properties. Food Science and Technology Research. 19(2): 237-243.

[2] Nurilmala, M. and Ochiai, Y. 2016. Molecular Characterization of Southern Bluefin Tuna Myoglobin (Thunnus maccoyii). Fish Physiology and Biochemistry. 110.

[3] Ahmad, M., Benjakul, S., and Nalinanon, S. 2010. Compositional and Physicochemical Characteristics of Acid Solubilized Collagen Extracted from the Skin of Unicorn Leatherjacket (Aluterus monoceros). Food Hydrocolloids Journal. 24: 588-594.

[4] Kittiphattanabawon, P., Benjakul, S., Visessanguan, W., and Shahidi, F. 2010. Comparative Study on Characteristics of Gelatin from the Skins of Brownbanded Bamboo Shark and Blacktip Shark as Affected by Extraction Conditions. Food Hydrocolloids Journal. 24: 164 171.

[5] Żelechowska, E., Sadowska, M., and Turk, M. 2010. Isolation and Some Properties of Collagen from The Backbone of Baltic Cod (Gadus morhua). Food Hydrocolloids Journal. 24: 325-329.

[6] Huang, Y. R., Shiau, C. Y., Chen, H. H., and Huang, B. C. 2011. Isolation and Characterization of Acid and Pepsin- 
Solubilized Collagens from The Skin of Balloon Fish (Diodon holocanthus). Food Hydrocolloids Journal. 25: 1507-1513.

[7] Zhu, B., Dong, X., Zhou, D., Gao, Y., Yang, J., Li, D., Zhao, $X .$, Ren, T., Ye, W., Tan, H., Wu, H., and Yu, C. 2012. Physicochemical Properties and Radical Scavenging Capacities of Pepsin-Solubilized Collagen from Sea Cucumber (Stichopus japonicus). Food Hydrocolloids Journal. 28: 182-188.

[8] Kumar, M. H., Spandana, V., and Poonam, T. 2011. Extraction and Determination of Collagen Peptide and Its Clinical Importance from Tilapia Fish Scales (Oreochromis niloticus). International Research Journal of Pharmacy. 2(10): 97-99.

[9] Gilsenan, P. M., and Ross-Murphy, S. B. 2000. Rheological Characterisation of Gelatins from Mammalian and Marine Sources. Food Hydrocolloids Journal. 14(3): 191-195.

[10] Muyonga, J. H., Cole, C. G. B., and Duodu, K. G. 2004. Characterisation of Acids Soluble Collagen from Skins of Young and Adult Nile Perch (Lates niloticus). Food Chemistry. 85: 81-89.

[11] Guillen, M. C. G., Gimenez, B., Caballero, M. E. L., and Montero, M. P. 2011 . Functional and Bioactive Properties of Collagen and Gelatin from Alternative Source: A Review. Food Hydrocolloids Journal. 25(8): 1813-1827.

[12] Karim, A. A., and Bhat, R. 2009. Fish Gelatin: Properties. Challenges. and Prospects as An Alternative to Mammalian Gelatins. Food Hydrocolloids Journal. 23: 563576.

[13] [AOAC] The Association of Official Analytical Chemist 2006. Official Methods of Analysis. 18 th edition. Washington DC (US): Association of Official Analytical Chemist.

[14] Singh, P., Benjakul, S., Maqsood, S., and Kishimura, H. 2011. Isolation and Characterisation of Collagen Extracted from The Skin of Striped Catfish (Pangasianodon hypophthalmus). Food Chemistry. 124: 97-105.

[15] Apriyantono, A., Fardiaz, D., Puspitasari, N. L., Sedamawati, Y., and Budianto, S. 1989. Petunjuk Laboratorium Analisis Pangan. Bogor (ID): Pusat Antar Universitas Pangan dan Gizi Institut Pertanian Bogor

[16] [AOAC] Association of Official Analytical Chemyst. 1995. Official Method of Analysis of The Association of Official Analytical of Chemist. Virginia (US): The Association of Official Analytical Chemist Inc.
[17] Laemmli, U. K. 1970. Cleavage of Structural Protein during The Assembly of The Head of Bacterophage T4. Nature. 227: 680-685.

[18] Batubara, I., Mitsunaga, T., and Ohashi, H. 2009. Screeneing Antiacne Potency of Indonesian Medicina Plants: Antibacterial. Lipase Inhibition. and Antioxidant Activities. Journal of Wood Science. 55: 230-235.

[19] Steel, R. G. D., Torrie, J. H. 1993. Prinsip dan Prosedur Statistika. Suatu Pendekatan Biometrik. Sumantri B. translator. Jakarta (ID): Gramedia Pustaka Utama. Terjemahan dari: Principles and Procedures of Statistics: A Biometrical Approach.

[20] Zhou, P., and Regenstein, J. M. 2005. Effects of Alkaline and Acid Pretreatments on Alaska Pollock Skin Gelatin Extraction. Journal of Food Science. 70(6): 392-396.

[21] Potaros, T., Raksakulthai, N., Runglerdkreangkrai, J., and Worawattanamateekul, W. 2009. Characteristics of Collagen from Nile Tilapia (Oreochromis niloticus) Skin Isolated by Two Different Methods. Kasetsart Journal. 43: 584-593.

[22] Kong, J., and Yu, S. 2007. Fourier Transform Infrared Spectroscopic Analysis of Protein Secondary Structures. Acta Biochim Biophys Sin. 39 (8): 549-559.

[23] Yata, M., Yoshida, C., Fujisawa, S., and Yoshinaka, Y. 2001. Identification and Characterization of Molecular Species of Collagen in Fish Skin. Journal of Food Science. 66: 247251.

[24] Jongjareonrak, Benjakul, A., S., Visessanguan, W., Nagai, T. and Tanaka, M. 2005. Isolation and Characterisation of Acid and Pepsin-solubilised Collagens from The Skin of Brownstripe Red Snapper (Lutjanus vitta). Food Chemistry. 93: 475-484.

[25] Cohen-Solal, L., Louis, M. L., Allian, J. C., and Meunier, F. 1981. Absence of Maturation of Collagen Crosslink's in Fish Skin. FEBS Letters. 123: 282-284

[26] Li, B., Chen, F., Wang, X., Ji, B., and Wu, Y. 2007. Isolation and identification of Antioxidative Peptides from Porcine Collagen Hydrolysate by Consecutive Chromatography and Electrospray Ionization-mass Spectrometry. Food Chemistry. 102(4): 1135-1143.

[27] Li, C., Sun, J., and Zhang, H. 2011. Extraction and Antioxidant Activity of Collagen from Elephant Skin, Pig Skin and Fish Scales. China Journal of Chinese Materia Medica. 36(16): 2183-2186. 